\section{Etika Pejabat Publik dan Kualitas Pelayanan Publik di Lingkungan Pemerintahan Kabupaten Tangerang}

\author{
Wawan 1), Yeby Ma'asan Mayrudin 2) \\ 1) Program Studi Ilmu Pemerintahan, \\ Universitas Sultan Ageng Tirtayasa, \\ Indonesia. \\ 2) Program Studi Ilmu Pemerintahan, \\ Universitas Sultan Ageng Tirtayasa, \\ Indonesia. \\ *Korespondensi Penulis. E-mail: \\ yeby@untirta.ac.id
}

\begin{abstract}
Abstrak
Artikel ini memeriksa tentang persoalan pengejawantahan etika publik oleh pejabat publik yang disinyalir akan berdampak terhadap kualitas penyelenggaraan pelayanan publik. Persoalan tersebut menunjukkan adanya keselarasan penerapan etika publik akan menentukan bagaimana nilai kualitas penyelenggaraan pelayanan oleh pejabat publik. Namun permasalahannya adalah apakah para pejabat publik sesungguhnya menerapkan nilai-nilai etika ataukah nir-etika dalam pelayanan publik terhadap seluruh masyarakat? Lokus yang tim penulis lacak terfokus pada penyelenggaraan pelayanan publik di lingkungan pemerintahan Kabupaten Tangerang, Provinsi Banten. Dalam memeriksa hal tersebut, kami menggunakan kerangka teori Etika Publik dan Pelayanan Publik sebagai pisau analisa. Adapun metode penelitiannya menggunakan metode kualitatif deskriptif. Dengan varian ini akan mampu menyajikan persoalan secara deskriptif terkait dengan pokok permasalahan. Selanjutnya, tulisan ini sesungguhnya membuktikan adanya pengaruh penerapan etika terhadap kualitas pelayanan publik. Sayangnya, tim penulis
\end{abstract}

mendapati bahwa kualitas pelayanan publik di lingkungan Kabupaten Tangerang masih kurang optimal dalam memanifestasikan etika publik.

Kata Kunci: Etika Politik, Pejabat Publik, Pelayanan Publik, Nir-Etika

\section{Ethics of Public Officials and Quality of Public Services in Tangerang District Government}

\begin{abstract}
This article examines the issue of manifesting public ethics by public officials who allegedly will have an impact on the quality of the implementation of public services. The issue shows the alignment of the application of public ethics will determine how the value of service quality by public officials. But the problem is whether public officials actually apply ethical values or nir-ethics in public services to all citizens? The writer's team determined a locus focused on public services within the Tangerang Regency, Banten Province. In examining this issue, we use the theoretical framework of Public Ethics and Public Service as a tool for its analysis. The research method uses descriptive qualitative methods, with this variant will be able to present problems descriptively related to the subject matter. Furthermore, this paper actually proves the effect of applying ethics to the quality of public services. As a result, we find that the quality of public services in Tangerang Regency government has not been optimal in manifesting public ethics.
\end{abstract}

Keywords: Political Ethics, Public Officials, Public Services, Nir-Ethics 


\section{A. PENDAHULUAN}

Etika publik menjadi aspek yang sangat penting untuk menyelenggarakan pelayanan publik yang optimal kepada masyarakat. Penerapan etika publik memiliki dampak yang besar bagi kualitas pelayanan publik, Namun permasalahannya di Indonesia para pejabat publik yang memiliki tugas sebagai penyelenggara pelayanan publik kerap kali abai terhadap penerapan etika. Tentu saja konsekuensi logis dari keadaan ini adalah terjadinya degradasi kualitas pelayanan publik di Indonesia. buruknya kualitas pelayanan publik secara pararel akan berimbas pada terabaikannya hak-hak dari masyarakat untuk mengakses layanan publik. Dampak yang lebih mengerikan dari minimnya penerapan etika oleh pejabat publik adalah tindakan melanggar aturan oleh sejumlah pejabat publik karena praktik nir-etika yang terjadi membuat pejabat publik gagal memisahkan mana kepentingan publik yang harus diprioritaskan dan mana kepentingan pribadi atau kelompok. Tercampurnya kepentingan itu membuat kepentingan publik kerap tersisih dan pada akhirnya yang dirugikan adalah masyarakat. Sebagaimana disampaikan oleh (Kusumawati, 2019) bahwa permasalahan pada pejabat publik khususnya dalam pelayanan publik di Indonesia adalah permasalahan etika, bahkan tindakan pidana seperti Korupsi, Kolusi dan Nepotisme (KKN) bersumber dari perilaku nir-etika.

Hal demikian itu, diperkuat dengan beberapa temuan dari hasil penelusuran (Sommaliagustina, 2019) yang mengungkap praktik nir-etika oleh para pejabat publik. Dia mengatakan bahwa tingginya angka operasi tangkap tangan oleh Komisi Pemberantasan Korupsi (KPK) dari tahun 2005 sampai saat ini terdapat ratusan kepala daerah dan pejabat publik menjadi tersangka praktik KKN. Praktik nir-etikanya beragam mulai dari gratifikasi perijinan, kasus tender proyek, pengadaan barang/jasa, penyusunan anggaran dan seterusnya. Tanpa pengejawantahan praktik etika publik, para pejabat publik cenderung larut dalam praktik nir-etika seperti memanfaatkan dan menyalahgunakan kekuasaan dan kewenangannya untuk kepentingan pribadi maupun kelompoknya. Berikut di bawah ini beberapa data yang dilansir oleh Indonesian Corruption Watch (ICW) tahun 2019 mengenai lembaga publik dan aktor pejabat publik yang terindikasi melakukan tindak korupsi yang artinya mereka melakukan pelayanan publik yang nir-etika. 


\begin{tabular}{|c|c|c|c|c|c|c|}
\hline No & Keterangan & Jumlah kasus & $\begin{array}{c}\text { Nilai Kerugian } \\
\text { Negara }\end{array}$ & Nilai Suap & Nilai Pungli & $\begin{array}{c}\text { Nilai Pencucian } \\
\text { Uang }\end{array}$ \\
\hline 1. & Pemerintah Kabupaten & 95 & Rp6,1 triliun & Rp42,8 miliar & Rp2,1 miliar & Rp62 miliar \\
\hline 2. & Pemerintah Desa & 48 & Rp32,7 miliar & - & Rp212 juta & - \\
\hline 3. & Pemerintah Kota & 23 & Rp40,9 miliar & Rp1,2 miliar & Rp185 juta & \\
\hline 4. & Kementerian & 20 & Rp259,9 miliar & Rp58,2 miliar & - & - \\
\hline 5. & BUMN & 18 & Rp1,3 triliun & Rp84,5 miliar & Rp1 miliar & Rp46 miliar \\
\hline 6. & Pemerintah Provinsi & 16 & Rp130 miliar & Rp153 juta & Rp11 juta & - \\
\hline 7. & Badan/Lembaga Negara & 10 & Rp117,6 miliar & Rp16,6 juta & - & - \\
\hline 8. & DPRD & 9 & Rp9o,8 miliar & Rp4,8 miliar & - & - \\
\hline 9. & BUMD & 8 & Rp199 miliar & - & - & - \\
\hline 10. & $\begin{array}{l}\text { Penegak Hukum } \\
\text { (kejaksaan, kepolisian, } \\
\text { pengadilan) }\end{array}$ & 6 & - & Rp482 juta & Rp40 juta & - \\
\hline
\end{tabular}

Gambar 1. Kasus Korupsi Berdasarkan Lembaga (10 Besar)

Sumber: Indonesian Coruption Watch [ICW], 2019

Permasalahan etika yang menjangkiti pejabat publik di Indonesia parahnya tidak hanya terjadi pada level nasional melainkan juga pada level lokal yaitu pemerintahan daerah baik di tingkat provinsi maupun kabupaten/kota. Di Provinsi Banten misalnya sejumlah permasalahan yang terjadi juga tidak terlepas dari terabaikannya etika oleh pejabat publik sebagai penyelenggara pelayanan terhadap publik. Dikutip dari (Sindonews.com, n.d.) bahwa praktik nir-etika di provinsi tersebut dapat ditemui pada muncul dan terkonsolidasinya dinasti politik Chasan Sochib. Tindakan memobilisasi keluarga untuk menduduki jabatan politik dan menguasai daerah tertentu dianggap bertentangan dengan nilai etika demokratisasi. Ternyata benar terjadi ketika anggota dinasti tersebut satu-persatu terbukti melakukan tindakan pidana Korupsi. Dengan contoh konkrit tersebut kita tidak ragukan lagi bahwa sesungguhnya peran etika sangat penting dan perilaku pejabat publik yang nir-etika tidak hanya berimbas pada buruknya kualitas pelayanan publik melainkan bisa menimbulkan tindakan pidana yang merugikan masyarat. Pada banyak kasus korupsi di Provinsi Banten, kita bisa melihat bagaimana pejabat publik yang berpraktik niretika terlihat gagal memisahkan kepentingan publik dengan kepentingan pribadi atau kelompoknya saja sehingga justru berdampak pada rendahnya kualitas pelayanan terhadap masyarakat yang sangat membutuhkan kehadiran negara. 


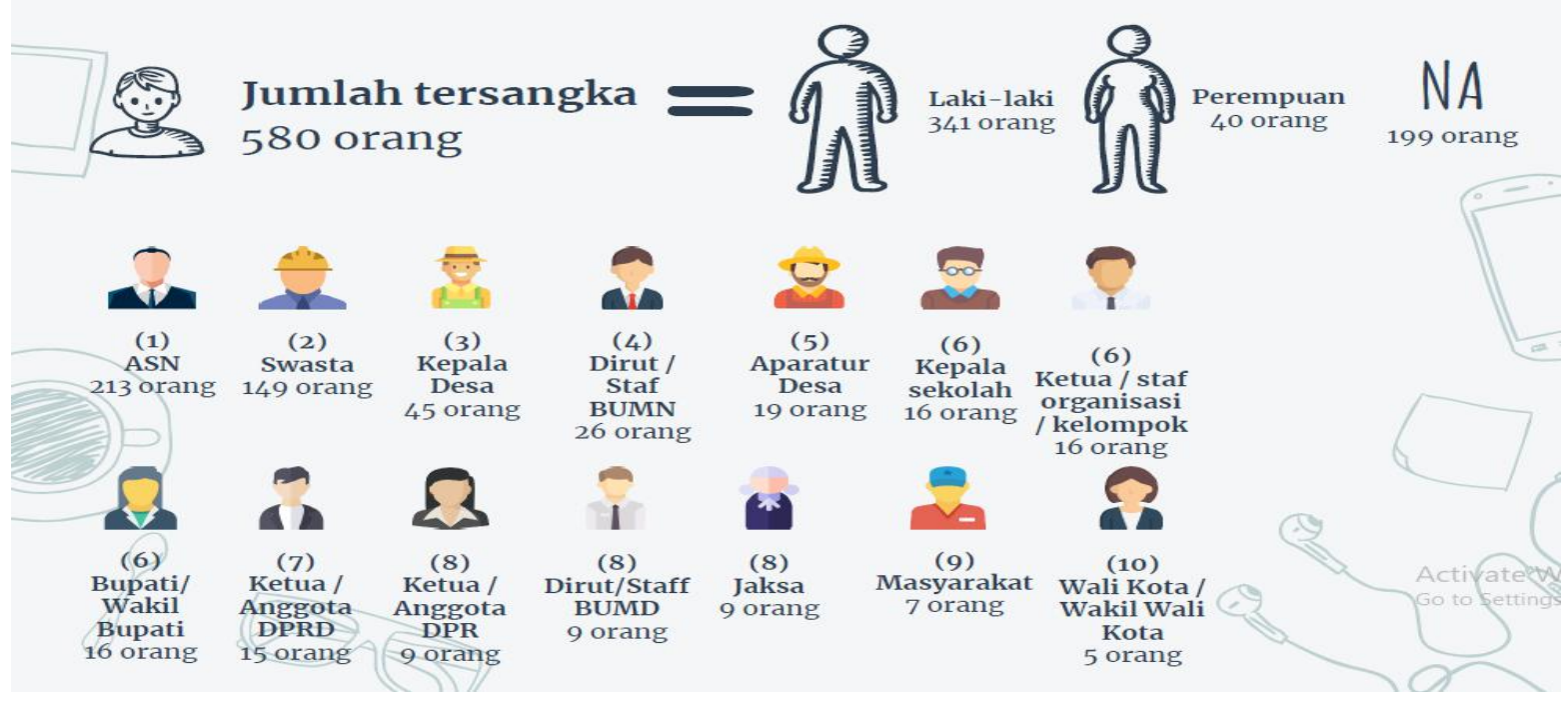

Gambar 2. Kasus Korupsi Berdasarkan Aktor

Sumber: Indonesian Corruption Watch [ICW], 2019

Mengingat pentingnya penerapan etika oleh pejabat publik terkhusus dalam pelayanan publik, maka kami tertarik untuk melihatnya secara lebih empirik pada etika pejabat publik di lingkungan pemerintahan Kabupaten Tangerang, Banten. Pasalnya ada beberapa indikator yang menunjukan bahwa etika publik di Kabupaten Tangerang cukup baik, misalnya didapatinya beberapa penghargaan terkait pelayanan publik dan prestasi lainnya dalam penyelenggaraan pemerintahan.

Adapun beberapa prestasi yang diperoleh Kabupaten Tangerang seperti pada November 2019 Kabupaten Tangerang mendapatkan penghargaan dalam hal pelayanan publik dari Kementerian Pendayagunaan Aparatur Negara dan Reformasi Birokrasi (KemenpanRB) Republik Indonesia. Di samping itu, dikabarkan juga oleh media daring (Bantenhits.com, n.d.) pada 2019 Kemenpan RB tetapkan SP4N-LAPOR Kabupaten Tangerang sebagai percontohan Nasional. Sebelumnya, pada tahun 2017 Kabupaten Tangerang juga pernah berhasil meraih Award Top 40 atas Inovasi Pelayanan Publik (Kabar-banten.com, n.d.)

Atas dasar beberapa pencapaian prestasi di bidang pelayanan publik itulah kami tertarik untuk mengetahui sebenarnya bagaimana pelayanan publik di Kabupaten Tangerang dengan mengambil persepsi dari masyarakat dan media massa yang lebih netral. Kami juga ingin membongkar bagaimana praktik manifestasi etika pejabat publik dalam pelayanan publik di daerah tersebut. Di sini kami akan membedah apakah sejumlah prestasi itu diperoleh dengan disertai penerapan etika yang baik atau jangan-jangan masih banyak perilaku dan praktik nir-etika para 
pejabat publiknya yang tersamarkan oleh penghargaan tersebut. Kami juga akan membongkar apakah perilaku niretika dapat menyelundup ke dalam prestasi dan penghargaan yang diperoleh oleh pemerintah daerah ini. Artinya relevansi antara penerapan etika atau nir-etika akan memunculkan penilaian baik atau buruknya kualitas pelayanan publik. Maka dari itu, kami akan menelaah secara lebih mendalam karena sebagaimana disampaikan sebelumnya bahwa penerapan praktik nir-etika tidak mungkin menghasilkan pelayanan publik yang berkualitas. Tentu saja fokus kami bukan untuk menguji kredibilitas dari penghargaan dan prestasi itu, melainkan untuk melihat muatan etika pejabat publik dan korelasinya dengan kualitas pelayanan publik yang diselenggarakannya.

Dalam membedah tentang laku etika pejabat publik dan kaitannya dengan kualitas pelayanan publik beberapa penelitian sejenis pernah dilakukan oleh beberapa peneliti dan mendapatkan temuan-temuan yang menarik. Seperti riset yang pernah dilakukan oleh (Bisri, et. al., 2019) yang menelaah tentang etika pelayanan publik di Indonesia, hasilnya ia menemukan bahwa permasalahan mendasar dalam proses pelayanan publik di Indonesia adalah tentang etika. Penyebabnya adalah karena tidak ada standar universal tentang norma atau etika serta sanksi yang mengatur secara khusus untuk pelanggaran yang dilakukan aparat dalam pelayanan publik. Kemudian (Kusumawati, 2019) dalam risetnya membedah persoalan tentang harmonisasi antara etika publik dengan kebijakan publik. Ia mengungkap temuan risetnya adalah bahwa ketika pejabat publik tidak mampu memisahkan secara tegas antara domain publik dan pribadi, maka akan berkorelasi negatif terhadp pelayanan publik. Penelitian sejenis juga dilakukan oleh (Zega, 2018) yang berusaha menggali penerapan etika birokrasi dalam pelayanan publik pada Dinas Kependudukan dan Pencatatan Sipil Kota Gunungsitoli. Hasil risetnya ialah mengungkap temuan bahwa perilaku etika birokrasi pada pelayanan publik di sana terbilang cukup baik karena mendapatkan respon kepuasan dari masyarakat.

Dari ketiga kajian tersebut setidaknya terlihat perbedaan dengan penelitian yang kami kerjakan dan memiliki kebaruan karena menyoal ada atau tidaknya keselarasan penerapan etika publik dalam menentukan kualitas penyelenggaraan pelayanan oleh pejabat publik. Pokok permasalahan yang kami fokuskan adalah menyelisik tindakan para pejabat publik di lingkungan pemerintahan Kabupaten Tangerang sesungguhnya mengaplikasikan nilainilai etika ataukah nir-etika dalam pelayanan publik terhadap seluruh masyarakat.

Dengan demikian, mengetahui pengaruh dari etika pejabat publik terhadap pelayanan yang diberikan menjadi hal yang sangat penting karena 
jika terdapat hubungan yang signifikan antara laku etika pejabat dengan tingkat pelayanan publik maka akan muncul fakta ilmiah baru bahwa pelayanan publik tidak dapat lepas dari etika pejabat publik. Sehingga jika demikian adanya maka evaluasinya adalah meningkatkan pelayanan publik harus dibarengi pula dengan peningkatan laku etika yang terukur bagi para pejabat publiknya. Namun jika sebaliknya bahwa laku etika pejabat publik tidak memiliki pengaruh terhadap tingkat pelayanan publik maka ini juga akan memunculkan fakta ilmiah baru bahwa kualitas pelayanan publik tidak dipengaruhi oleh etika pejabatnya melainkan oleh faktor lain yang harus ditelaah dan dimaksimalkan agar terwujud pelayanan publik yang berkualitas.

\section{B. TEORI (Literature Review)}

\section{Etika Publik}

Sebelum menjelaskan konsepsi etika publik, kami menilai sangat perlu juga menyajikan penjabaran mengenai makna konseptual dan operasional tentang etika. Franz Magnis Suseno menyebut pemaknaan secara konsep dan praktiknya, etika terbagi menjadi dua, yaitu (1) etika umum yang memeriksa prinsip atau nilai dasar bagi segenap perilaku atau tindakan manusia dan (2) etika khusus yang menjabar terkait prinsip-prinsip atau nilai atas perilaku atau tindakan manusia dalam korelasinya dengan kewajiban manusia dalam berbagai lingkup kehidupannya (Suseno, 2018).

Selanjutnya, bila mengacu pada pendapat (Bertens, 2013) pemaknaan mengenai etika dapat digolongkan menjadi tiga arti, yaitu: "[1]...nilai-nilai dan norma-norma moral yang menjadi pegangan bagi seseorang atau suatu kelompok dalam mengatur tingkah lakunya. [2]...kumpulan asas atau nilai moral. Yang dimaksud di sini adalah kode etik. [3]...ilmu tentang yang baik atau buruk." Dia kemudian melanjutkan penjelasannya bahwa di dalam etika biasanya terdapat kesatuan makna yang melekat dengan hati nurani. Hati nurani ini merupakan bagian yang ada dalam diri setiap manusia yang menilai tentang moralitas perbuatannya maupun manusia lain.

Lebih lanjut, tidak mengikuti hati nurani berarti menghancurkan integritas pribadi kita dan mengkhianati martabat terdalam kita. Dapat dikatakan juga, hati nurani adalah kesadaran moral: "instansi" yang membuat kita menyadari baik atau buruk (secara moral) dalam perilaku kita. Dengan demikian hati nurani berkaitan erat dengan kenyataan bahwa manusia mempunyai kesadaran. (Bertens, 2013)

Maka dari itu, praktik etika yang mengedepankan hati nurani akan mampu mengejawantahkan nilai-nilai atau norma-norma berkelakuan yang positif dan elok. Dengan begitu, etika akan mampu mengarahkan pada praktik keajegan sosial yang penuh harmoni. Apabila mengaitkan dengan praktik 
etika umum dan khusus tersebut dengan etika publik yang seyogyanya diterapkan dan dijalankan oleh para pejabat publik di negara ini maka tidak mungkin tidak kemaslahatan, kesejahteraan dan keadilan sosial akan terwujud di negara ini.

Daripada itu, maka pada bagian ini kami akan coba menyajikan konsepsi tentang etika publik. Kami melandaskan konsepsi pemaknaan etika publik pada formulasi yang sudah dirancang oleh (Haryatmoko, 2011), yang menyebut bahwa etika publik ini sesungguhnya menegaskan pada standard dalam menentukan bahkan menilai suatu tindakan pejabat publik itu baik atau buruk di dalam ranah pelayanan publik. Selanjutnya, ia menjelaskan tentang tujuan etika publik yaitu untuk menjamin integritas para pejabat pemerintahan dalam menyelenggarakan pelayanan publik bagi semua masyarakat. Dia juga menyatakan bahwa etika publik ini mendorong tiga kompetensi seorang pejabat publik, yaitu: (1) kompetensi etika; (2) kompetensi teknis; dan (3) kompetensi kepemimpinan. Pertama, kompetensi etika yang dimaknai sebagai muatan utama dan pertama bagi praktik etika publik. Artinya para pejabat publik sesungguhnya perlu memahami dan mempraktikkan nilai-nilai dan normanorma etika dalam melayani segenap kehendak masyarakat. Kedua, kompetensi teknis merupakan kemampuan para pejabat publik dalam menjalankan Standard Operasional
Procedure (SOP) yang mengedepankan sisi etika humanis dibanding sisi etika birokratis yang kaku. Ketiga, kompetensi kepemimpinan (leadership) mengacu pada kemampuan seorang pemimpin atau pejabat publik dalam mendorong jajarannya mewujudkan pelayanan publik yang prima dan berintergritas.

Kemudian, berdasar pada eksplorasi itu, kami menilai bahwa ketiga kompetensi tersebut merupakan bagian yang terintegral dalam mengejawantahkan praktik etika publik bagi para pejabat pemerintahan dalam pelayanan urusan publik kepada segenap masyarakat. Maka kalau saja implementasi etika publik oleh para pejabat publik dalam penyelenggaraan urusan kemasyarakatan dijalankan secara massif, diharapkan mampu mendorong kemaslahatan bersama. Namun sayangnya, tidak sedikit pejabat publik justru mempraktikkan laku niretika publik dalam melayani urusan kemasyarakatan. Alhasil, praktik niretika memunculkan sejumlah momok menakutkan seperti maraknya korupsi, kolusi dan nepotisme, pelayanan yang tidak berkeadilan dan patologi birokrasi serta penyalahgunaan wewenang (abuse of power). Oleh sebab itu, urgensi penerapan etika publik yang terinci pada tiga kompetensi etika, teknis dan kepemimpinan sepatutnya dimanifestasikan oleh segenap pejabat publik. Maka sudah sepatutnya tim penulis menjadikan ketiga kompetensi tersebut dijadikan sebagai pisau analisa 
dalam menilai pengaruh praktik etika pejabat publik dalam penyelenggaraan layanan kemasyarakatan di lingkungan pemerintahan Kabupaten Tangerang.

\section{Kualitas Pelayanan Publik}

Kualitas pelayanan menurut Brady dan Conin (dalam Rezha, et. al., 2013) adalah perbandingan antara apa yang didapatkan penerima layanan dengan harapan yang diinginkan oleh penerima layanan tersebut. Artinya kualitas layanan dapat dinilai dari apa yang diinginkan oleh penerima layanan tersebut. Bersandar pada formulasi tersebut, maka bila apa yang didapatkan oleh penerima layanan sesuai dengan apa yang mereka harapkan maka kualitas layanan publik bisa dikatakan baik.

Adapun menurut (Pasolong, 2007) mengatakan bahwa untuk menilai baik buruknya suatu pelayanan publik yang diberikan oleh para pejabat publik dapat dilihat dari baik buruknya penerapan lima indikator di bawah ini, yaitu a) Efisiensi, yaitu para birokrat tidak boros dalam melaksanakan tugas-tugas pelayanan kepada masyarakat. Dalam artian bahwa para birokrat secara berhati-hati agar memberikan hasil yang sebesar-besarnya kepada publik; b) Efektivitas, yaitu pada birokrat dalam melaksanakan tugas-tugas pelayanan kepada publik harus baik (etis) apabila memenuhi target atau tujuan yang telah ditentukan sebelumnya tercapai. Tujuan yang dimaksud adalah tujuan publik bukan tujuan pemberi pelayanan (birokrasi publik); c) Kualitas layanan, yaitu kualitas pelayanan yang diberikan oleh pada birokrat kepada publik harus memberikan kepuasan kepada yang dilayani; d) Responsivitas, yaitu berkaitan dengan tanggung jawab pejabat publik dalam merespon kebutuhan publik yang sangat mendesak. Mereka dalam menjalankan tugasnya dinilai baik (etis) jika sangat responsif dan memiliki profesionalitas yang tinggi; e) Akuntabilitas, yaitu berkaitan dengan pertanggungjawaban dalam melaksanakan tugas dan kewenangan pelayanan publik. Birokrat atau pejabat publik yang baik (etis) adalah yang akuntabel dalam melaksanakan tugas dan kewenangannya.

Selanjutnya, penyelenggara layanan publik menurut (Maani, 2010) yang menjelaskan bahwa para pejabat publik tidak mungkin dilepaskan dari praktik atau penerapan nilai-nilai etika publik. Karena hal itu sangat berkaitan dengan soal baik dan buruk di dalam tindakan manusia, maka tugas-tugas dari pejabat publik sebagai pelayan publik tidak terlepas dari hal-hal tersebut. Dalam jurnalnya, ia juga disampaikan bahwa pejabat publik harus memiliki tindakan/praktik "melayani, bukan dilayani"; "mendorong, bukan menghambat"; "mempermudah, bukan mempersulit"; "sederhana, bukan berbelit-belit". Standard pelayanan publik tersebut diperlukan untuk pemenuhan atau perwujudan nilai-nilai dan norma-norma atas sikap dan perilaku para pejabat publik dalam 
setiap pelayanan dan tindakannya untuk memberikan pelayanan prima terhadap masyarakat luas. Adapun menurut (Denhardt, 1988) pejabat publik wajib memiliki sikap, mental dan perilaku yang mencerminkan keunggulan watak, keluhuran budi, dan asas etis. Ia wajib mengembangkan diri agar sungguhsungguh memahami, menghayati, dan menerapkan berbagai asas etis yang bersumber pada kebajikan-kebajikan moral khususnya keadilan dalam tindakan jabatannya.

\section{METODE}

Metode dalam penelitian ini menggunakan metode kualitatif deskriptif. Metode kualitatif dinilai kompatibel untuk menganalisa dan memahami fenomena terkait praktik sosial politik dan tindakan aktor secara holistik. Kemudian varian penelitian ini akan mampu mengejawantahkan data deskriptif dalam beragam bentuk dari mulai hal yang tertulis, ungkapan lisan maupun tindakan aktor atau aksi kelompok yang diteliti Adapun teknik pengumpulan data yang tim penulis gunakan yaitu metode wawancara terhadap pejabat publik di lingkungan Pemerintahan Kabupaten Tangerang dan kepada beberapa warga Kabupaten Tangerang- serta metode observasi partisipatoris dengan secara langsung mengikuti proses layanan publik yang diselenggarakan oleh Pemkab. Tangerang. Hal demikian itu, akan bermanfaat sebagai bahan atau data primer dalam menunjang kekokohan penelitian ini. Sedangkan data sekunder diperoleh dengan melakukan studi literatur dari beberapa sumber media dan juga artikel jurnal serta naskah buku.

Jadi dalam tulisan ini kami membahas tentang fakta sebenarnya dari pelayanan publik di lingkungan pemerintahan Kabupaten Tangerang. Fakta tersebut akan digali dari keterangan masyarakat Kabupaten Tangerang dan didukung dari data sekunder dari media massa. Sedangkan laku etika pejabat publik yang akan kita analisis diperoleh dari wawancara langsung dengan Wakil Bupati Kabupaten Tangerang, Mad Romli. Etika pejabat publik juga akan digali dari masyarakat dengan mencari tahu pengalaman mereka dalam menggunakan fasilitas pelayanan publik.

Selanjutnya data-data yang sudah didapat akan ditinjau dengan sudut pandang teori dan akan dilakukan triangulasi untuk menguji validitas suatu fakta atau fenomena. Data dalam penelitian ini diolah dengan cara melakukan analisis yang memakai beberapa konsepsi seperti Etika Publik dan Pelayanan Publik. Teori-teori tersebut berperan sebagai pisau analisa yang akan membantu tim penulis dalam menemukan jawaban dari pertanyaan penelitian yang diajukan. Kemudian hasil penelitian akan diurai secara deskriptif argumentatif pada bagian pembahasan yang mengacu pada penelisikan atas fakta atau fenomena yang ditemukan dalam penelitian ini. 
D. HASIL DAN PEMBAHASAN

\section{Pelayanan Publik di Kabupaten Tangerang}

Kabupaten Tangerang diklaim memiliki label baik di bidang Pelayanan Publik, hal ini bisa dilihat dari beberapa penghargaan terkait tentang pelayanan publik di Kabupaten Tangerang. Seperti dikutip dari bantenhits.com (25/09/2019) pada tahun 2019 Kemenpan RB tetapkan SP4N-LAPOR Kabupaten Tangerang sebagai percontohan Nasional. Lalu pada November 2019 Kemenpan RB kembali memberikan penghargaan kepada Pemerintah Kabupaten Tangerang dalam hal ini OPD RSUD Balaraja dengan predikat pelayanan publik sangat baik. Beberapa Prestasi tersebut juga dikonfirmasi oleh Wakil Bupati Tangerang, Romli. Dalam kesempatan wawancara dengannya, ia juga menambahkan bahwa Kabupaten Tangerang mendapatkan penghargaan dalam hal pelayanan KTP-Elektronik (KTP-El).

Penjelasan Wakil Bupati Tangerang serta data-data dari media menunjukan bahwa pelayanan publik di Kabupaten Tangerang memang memiliki peringkat yang bagus. Namun di sini kami berusaha menggali fakta tentang pelayanan publik ini dari perspektif masyarakat selaku pengguna layanan publik. Dari beberapa informan dalam wawancara kami ketika ditanya tentang bagaimana pelayanan publik yang mereka rasakan di Kabupaten Tangerang. Seperti penjelasan salah satu informan kami (SP 20 th), ia pernah mengurus KTP-El di Dinas Kependudukan dan Catatan sipil Kabupaten Tangerang dan ia menjelaskan bahwa pelayanan disana cukup responsif, bahkan KTP-El langsung jadi hari itu juga, namun menurutnya sosialisasi terkait jadwal pengurusan KTP-El belum efektif dan menyebar secara luas kepada masyarakat Kab. Tangerang karena menurutnya masih banyak masyarakat yang belum mengetahui jadwal tersebut.

Informan lain berinisial RA (21 th) mengaku pernah membantu saudaranya mengurus administrasi untuk menggunakan layanan BPJS di salahsatu Rumah Sakit di Kabupaten Tangerang. Ia mengaku petugas layanan disana juga cukup baik dalam merespon kebutuhan yang mendesak semacam itu. Penjelasan dari pengguna layanan Publik di Kabupaten Tangerang memperlihatkan bahwa pelayanan publik disana mendapatkan pengakuan relatif baik meskipun ada beberapa aspek yang masih harus ditingkatkan lagi. Sejalan dengan apa yang disampaikan (Pasolong, 2007) bahwa untuk menilai baik buruknya suatu pelayanan publik maka salah satu indikator nilai yang dapat dilihat adalah Responsifitas dan kualitas yang ukurannya adalah kepuasan dari pengguna layanan tersebut. Dari data yang ada jika dilihat dari sisi responsifitas dan kualitas maka pelayanan publik di Kabupaten Tangerang belum dapat sepenuhnya 
dikatakan baik karena pada beberapa aspek masih terdapat kekurangan yang harus diperbaiki. Pada pelayanan E-KTP misalnya pengguna layanan mengaku puas karena petugas responsive tetapi pada bagian yang lain misal tentang sosialisasi jadwal pengurusan E-KTP ditemukan masih sangat kurang sehingga banyak pengguna layanan tidak mengetahui penjadwalan berdasar domisili.

Kemudian Wakil Bupati Kabupaten Tangerang, Romli juga menjelaskan bahwa para pegawaipegawai di lingkungan Pemkab. Tangerang selama ini memang memiliki kinerja yang baik, salah satunya mereka selalu memenuhi target. Salah satu contohnya ialah ia menekankan bahwa setiap Rumah Sakit di Kabupaten Tangerang mampu mengakomodir pengguna layanan Badan Penyelenggara Jaminan Sosial (BPJS) Kesehatan. Artinya rumah sakit tidak boleh menolak pengguna layanan BPJS Kesehatan dengan alasan apapun, sekalipun kapasitas rumah sakit terbatas. Hal itu dilakukan oleh rumah sakit yang berada di bawah kewenangan Pemkab. Tangerang. Ia juga menjelaskan bahwa di daerahnya memilki empat rumah sakit yang siap melayani masyarakat. Dengan fakta tersebut (Pasolong, 2007) menjelaskan bahwa untuk menilai baik buruknya suatu pelayanan publik maka salah satu indikator yang dapat dilihat adalah nilai efektivitas. Artinya pelayanan publik harus dilakukan dengan etis dan mampu mencapai target yang ditentukan sebelumnya. Jadi pada pernyataan Wakil Bupati tersebut kita tidak bisa menilai bahwa dengan pemenuhan target dapat dikatakan efektif dan pelayanannya baik karena efektifitas harus relevan dengan apa yang didapatkan oleh penerima layanan tersebut. Jika seandainya target tercapai bahwa semua penerima BPJS Kesehatan dapat terlayani namun dengan cara yang dipaksakan karena tuntutan target maka kualitas layanan publik seketika menjadi tidak berkualitas.

Di samping itu Romli juga menyampaikan bahwa fasilitas pelayanan publik yang disediakan oleh Pemerintah Kab. Tangerang bernama SP4N-LAPOR sangat minim sekali penggunaannya oleh masyarakat. Fakta ini memperlihatkan bahwa efektifitas dari layanan publik tersebut masih sangat minim dan belum optimal. Setelah kami melakukan penggalian informasi terhadap informan maka jawaban atas persoalan ini adalah sesungguhnya masyarakat tidak sepenuhnya mengetahui tentang cara penggunaan fasilitas tersebut. Dengan begitu implementasi terkait sosialisasi tentang program ini tentu perlu ditingkatkan lagi terlebih pelayanan ini berbasis daring yang membutuhkan kecakapan teknologi informasi bagi penggunanya. Pada jawaban yang lain kami menemukan bahwa ada semacam ketidakpercayaan publik terhadap fasilitas pengaduan itu bahwa keluhan mereka akan benar-benar diproses 
menjadi kebijakan yang diharapkan oleh publik. Sekiranya oleh karena sebab itu, mereka yang sudah mengerti cara penggunaan sistem teknologi informasi pun menjadi apatis terhadap fasilitas pelayanan publik yang tersedia.

\section{Etika Petugas Penyelenggara Layanan Publik di Kabupaten Tangerang}

Pada bagian ini kami akan coba membongkar bagaimana penerapan etika yang dilakukan oleh petugas penyelenggara layanan publik di lingkungan pemerintahan Kab. Tangerang. Dari sini kita akan mengetahui apakah penyelenggara layanan publik menerapkan nilai-nilai etika atau justru nir-etika. Menurut penjelasan Romli, memang ia menyadari bahwa penerapan etika dalam proses penyelenggaraan pemerintahan sangatlah penting terutama yang berkaitan dengan pelayanan terhadap masyarakat. Ia menjelaskan bahwa selama ini ia dan jajaran pemerintah Kab. Tangerang selalu mendorong agar masyarakat diberikan pelayanan yang terbaik, bukan hanya baik dalam segi kualitas infrastruktur tapi juga baik dalam segi prakti etika publik. Ia menyampaikan bahwa selama ini penyelenggara pelayanan publik di lingkungan pemerintahan Kabupaten Tangerang selalu menjunjung kode etik.

Selain itu, Romli juga menyampaikan bahwa fasilitas publik bernama SP4N-LAPOR salah satunya diciptakan untuk mengakomodir keluhan dan pengaduan masyarakat terkait etika penyelenggara pelayanan publik di lingkungan pemerintahan Kabupaten Tangerang. Namun faktanya pengaduan masyarakat terkait tindakan pelanggaran kode etik oleh penyelenggara pelayanan atau pejabat publik hampir tidak ada, namun tidak ada pengaduan bukan berarti tidak ada pelanggaran kode etik. Apabila seorang pejabat publik atau birokrat penyelenggara pelayanan publik dalam bekerjanya nir-etika publik maka kinerja pelayanan publik menjadi buruk dan akan timbul banyak pengaduan dari masyarakat yang dilayani (Ismiyarto, 2016). Terlepas dari pendapat tersebut tetapi dalam riset ini kami menemukan bahwa minimnya laporan, pengaduan dan keluhan dari masyarakat ternyata bukan disebabkan karena tidak ada tuntutan tetapi karena sebagian masyarakat tidak mengetahui cara menggunakan fasilitas tersebut dan sebagian yang lain mengaku tidak percaya bahwa dengan menyampaikan aspirasi melalui SP4N-LAPOR akan menghasilkan kebijakan yang sesuai dengan keinginan dan harapan publik.

Sementara itu, salah satu informan menyampaikan kepada kami bahwa menurutnya pelayanan di rumah sakit yang ada di lingkungan pemerintahan Kabupaten Tangerang saat ini sudah cukup baik. Hal ini ia rasakan saat ada kerabatnya yang sakit dan yang bersangkutan menggunakan layanan rumah sakit melalui program BPJS Kesehatan yang disediakan oleh pemerintah. Ia mengakui bahwa proses 
pelayanan yang diberikan kepada pasien BPJS Kesehatan tidak ada unsur diskriminatif sekalipun ia hanya pengguna BPJS Kesehatan kelas tiga. Jadi pelayanan publik yang ada di sana sudah memiliki nilai equality yang mampu memberikan kesamaan perlakukan kepada pengguna layanan publik sehingga pengguna layanan merasa bahwa mereka diperlakukan dengan adil dan setara. Hal serupa disampaikan oleh (Denhardt, 1988) yang mengungkap bahwa dalam pelayanan publik ada beberapa standar nilai moral yang harus dipenuhi di antaranya adalah nilai kesamaan (equality) dan keadilan (justice). Jadi, pengakuan dari masyarakat Kabupaten Tangerang tersebut memperlihatkan adanya implementasi nilai moral pada pelayanan publik di daerah itu.

Sekali lagi bila mengacu pada formulasi (Haryatmoko, 2011) tentang etika publik menuntut tiga kompetensi pejabat publik yaitu kompetensi etika, teknis, dan kepemimpinan, maka ada beberapa temuan menarik yang kami dapati dari pengakuan beberapa masyarakat yang puas terhadap pelayanan publik karena laku etika dari pejabat publiknya. Namun jika kita pakai konsepsi tersebut sebagai perspektif yang lebih objektif untuk menentukan etika pada pejabat publik di lingkungan pemerintahan Kabupaten Tangerang, maka kita aka temukan bahwa manifestasi etika dalam penyelenggaraan pelayanan publik masih kurang optimal. Pasalnya pada ranah teknis misal kita akan menemukan bahwa ada beberapa hal seperti sosialisasi yang kurang massif terkait jadwal pengurusan KTP-El dan pemanfaatan layanan SP4N-LAPOR. Kemudian pembahasan tentang perlunya mendorong pembentukan kepemimpinan publik bagi pejabat publik agar memahami, menghayati dan mempraktikan etika (aktualisasi kompetensi etika) masih menjadi bagain yang belum difokuskan oleh pemerintah Kab. Tangerang. Hal demikian ini kami dapati setelah melakukan wawancara dengan Romli sebagai Wakil Bupati Tangerang. Meskipun ia mengaku bahwa para pegawainya selalu mematuhi aturan dan memenuhi target. Tetapi persoalan etika bukan hanya tentang itu melainkan juga tentang pertimbangan moral dari pejabat publik terkait etika publik yang dasarnya adalah hati nurani bukan sekedar tuntutan dan "paksaan" dari atasan semata (Bertens, 2013).

Sedangkan menurut (Nau, et. al., 2012) prinsip pengejawantahan etika dalam pelayanan publik dapat terlihat di antaranya dari tutur kata, sikap, dan perilaku para pemberi pelayanan publik. Berangkat dari pendapat tersebut, kami selaku tim penulis dalam observasi partisipatoris yang dilakukan saat menggunakan layanan publik di sana tepatnya ketika mengajukan permohonan wawancara dengan Wakil Bupati, kami mendapatkan perlakuan yang sesuai dengan standar administrasi yang berlaku dan dilayani sebagaimana 
mestinya, namun lagi-lagi semuanya seakan-akan dilakukan atas dasar tuntutan administrasi karena sikap ramah dan sopan yang berbasis hati nurani sebagaimana diungkapkan Bertens tidak kami rasakan. Begitupula yang diungkapkan oleh beberapa informan yang mengaku puas dalam pelayanan publik perihal administrasi sedangkan sangat minim pernyataan responden yang mengaku puas karena mendapatkan perlakuan santun atau adanya tutur kata yang baik dari penyelenggara layanan tersebut.

\section{Telaah Perwujudan Etika dan Kualitas Pelayanan Publik di Kabupaten Tangerang}

Setelah kita kuliti tentang pelayanan publik dan etika penyelenggara layanan publik di lingkungan pemerintahan Kabupaten Tangerang, maka pada bagian ini kami akan membahas tentang bagaimana pengaruh etika terhadap tingkat pelayanan publik. Jika (Maani, 2010) menjelaskan bahwa penyelenggara pelayanan publik atau pejabat publik sesungguhnya perlu mengejawantahkan nilai-nilai etika. Karena etika berkaitan dengan soal kebaikan dan keburukan di dalam hidup manusia, maka tugas-tugas dari birokrasi pelayan publik pun tidak terlepas dari hal-hal yang baik dan buruk. Sedangkan (Endah, 2018) menyampaikan bahwa penerapan etika oleh aparatur pemerintahan dapat menjadi kontrol dalam rangka melaksanakan tugas, fungsi dan kewenangannya dalam memberikan pelayanan kepada masyarakat.

\section{Kabupaten}

Tangerang mendapatkan sejumlah penghargaan dalam hal pelayanan publik. Dalam riset yang kami lakukan terhadap beberapa masyarakat dan pejabat di sana serta observasi langsung, maka kami menemukan bahwa memang benar pelaksanaan pelayanan publik sudah dilakukan dengan baik seperti pada pelayanan pasien BPJS Kesehatan dan pelayanan KTP-El. Namun setelah dikuliti lebih dalam ternyata masih terdapat beberapa hal yang dinilai kurang optimal dalam pelayanan publik tersebut misal dalam hal sosialisasi pengurusan jadwal KTP-El yang masih belum banyak diketahui oleh masyarakat Tangerang. Dengan fakta lapangan tersebut maka kita bisa melihat bahwa pelayanan publik di lingkungan pemerintah Kabupaten Tangerang masih belum sepenuhnya baik karena ada beberapa aspek yang masih harus ditingkatkan terutama mengenai sosialisasi jadwal pengurusan KTP-El berdasar pada basis domisili dan sosialisasi dan penggalangan penggunaan SP4N-LAPOR.

Fenomena sosial tersebut ditegaskan pula oleh (Bisri dan Asmoro, 2019) yang menyampaikan bahwa etika pelayanan publik adalah suatu tata cara dalam melayani publik dengan menggunakan kebiasaan yang mengandung nilai-nilai hidup dan hukum atau norma yang mengatur tingkah laku manusia yang dianggap 
baik. Jadi jika kita lihat fenomena tersebut memang benar bahwa pelayanan publik tidak mungkin bisa dilakukan dengan baik jika dipisahkan dengan etika. Karena etika memiliki definisi filosofi yaitu: (1) etika berkaitan dengan logika, berkaitan dengan benar dan salah; (2) etika berkaitan dengan perilaku juga baik dan buruk; (3) etika berkaitan dengan estetika yaitu selaras dan tak selaras, indah atau jelek (Endah, 2018). Jadi di sini kita bisa mulai melihat bahwa ternyata prestasi yang diperoleh pemerintah Kabupaten Tangerang terkait pelayanan publik tidak dinilai atas penerapan etika dalam proses pelayanannya. Karena faktanya kami menemukan bahwa manifestasi etika dalam pelayanan publik masih sangat minim diejawantahkan oleh kebanyakan pejabat publik yang ada di lingkungan pemerintahan Kab. Tangerang.

Fakta menunjukkan besarnya pengaruh etika terhadap kualitas pelayanan publik di Kabupaten Tangerang. Karena pelayanan publik yang sudah mendapatkan banyak prestasi dan penghargaan pun ternyata masih ditemukan kekurangannya ketika ditinjau dari perspektif etika publik. Jadi penghargaan atas sejumlah pelayanan publik di wilayah itu tidak dinilai berdasarkan muatan etika publik melainkan hanya dinilai dari pelaksanaan administrasi yang dilakukan. Pasalnya pada pelayanan publik yang mendapatkan penghargaan pun kami menemukan bahwa manifestasi etika dari penyelenggara pelayanan publik masih kurang optimal.

Jadi kualitas pelayanan publik tidak hanya dipengaruhi oleh sistem administrasi yang tertata rapih melainkan lebih besar dipengaruhi oleh laku etika penyelenggaranya. Jika pelayanan publik dilakukan dengan penerapan etika yang baik maka kualitas pelayanan pun akan baik pula. Namun jika sebaliknya pelayanan publik dilakukan dengan nir-etika maka kualitas pelayanan akan menjadi buruk. Pada kasus pelayanan publik di lingkungan pemerintahan Kabupaten Tangerang kita bisa melihat fenomena ini ketika digali dari perspektif etika publik. Ternyata data dan fakta yang diperoleh menunjukkan bahwa laku etika pejabat publik yang masih minim dipraktikkan di lingkungan pemerintahan Kabupaten Tangerang memengaruhi kualitas pelayanan publik dan kepuasan publik terhadap layanannya dinilai masih kurang optimal.

\section{E. SIMPULAN DAN SARAN \\ 1. Simpulan}

Dari riset yang kami lakukan akhirnya didapati kesimpulan bahwa kualitas pelayanan publik di lingkungan pemerintahan Kabupaten Tangerang memiliki keterkaitan yang sangat kuat dengan laku etika pejabat publik. Kualitas pelayanan yang memiliki predikat baik dan syarat dengan raihan prestasi serta penghargaan sekalipun ternyata masih ditemukan kekurangan ketika ditinjau dari perspektif etika 
publik. Sejumlah penghargaan terkait pelayanan publik tersebut ternyata tidak diukur berdasarkan muatan etika pejabat publiknya, melainkan hanya berdasar atas pelaksanaan admininstrasi saja. Pelayanan publik tidak bisa dilepaskan dari implementasi nilai-nilai etika. Semakin pelayanan dilakukan dengan syarat etika maka kualitas pelayanan yang diberikan kepada masyarakat juga akan semakin berkualitas. Namun jika pelayanan dilakukan dengan nir-etika maka kualitas pelayanan akan jauh dari kata baik.

\section{Saran}

Berdasarkan hasil penelitian ini maka kami menyarankan pertama, kepada pihak Pemerintah Kabupaten Tangerang khususnya dan kepada pemangku kepentingan secara umum agar pelayanan publik yang diberikan kepada masyarakat dimaksimalkan dengan mengejawantahkan muatan etika sebagai pokok yang penting dalam pelayanan, serta menerapkan dan mengawasi regulasi -baik dalam bentuk kode etik maupun slogan yang biasa tertera di spanduk- yang sudah ada secara tegas untuk mengatur laku etika penyelenggara pelayanan. Kedua, kami menyarankan kepada masyarakat agar senantiasa bersikap kritis apabila terdapat pelayanan publik yang terkesan nir-etika dan tidak menjalankan fungsi pelayanan dengan baik, maka masyarakat bisa menuntut haknya dengan melakukan pengaduan kepada pihak terkait. Ketiga, kami menyarankan kepada para civitas akademika agar terus melakukan pendalaman riset terkait praktik etika publik dalam pelayanan publik agar didapati standard etika bagi penyelenggaraan pelayanan publik yang berkualitas tinggi.

\section{Daftar Pustaka}

Bantenhits.com. (n.d.). Kemenpan RB Tetapkan SP4N LAPOR Kabupaten Tangerang Percontohan Nasional. In 25/09/2019. https://bantenhits.com/2019/09/2 5/kemenpan-rb-tetapkan-sp4nlapor-kabupaten-tangerangpercontohan-nasional/

Bertens, K. (2013). Etika (Kanisius).

Bisri, M. H., et al. (2019). Etika Pelayanan Publik di Indonesia. Journal of Governance Innovation, 1.

Denhardt, K. G. (1988). The Ethics of Public Service: Resolving Moral Dilemmas in the Public Organizations. New York: Greewood Press.

Endah, K. (2018). Etika Pemerintahan dalam Pelayanan Publik. Jurnal FISIP Universitas Galuh, 4(1).

Haryatmoko. (2011). Etika Publik. Gramedia Pustaka Utama.

Indonesian Coruption Watch (ICW) (2019). Kasus Korupsi Berdasarkan Lembaga (10 Besar). Laporan Riset. 
JSPG: Journal of Social Politics and Governance

Vol.2 No.1 Juni 2020

Ismiyarto. (2016). Etika dan Penyelenggaraan Pelayanan Publik. Jurnal Ilmu Pemerintahan - Suara Katulistiwa.

Kabar-banten.com. (n.d.). Pemkab Tangerang Raih Award Top 40 Inovasi Pelayanan Publik. https://www.kabarbanten.com/pemkab-tangerangraih-award-top-40-inovasipelayanan-publik/

Kusumawati, M. P. (2019). Harmonisasi antara Etika Publik dan Kebijakan Publik. 6(1), 1-23.

Maani, Karjuni D. (2010). Etika Pelayanan Publik. DEMOKRASI, 4(1).

Nau, Maria Yohana., et. al. (2012). Peran Etika dalam Pelayanan Publik Sesuai Pembangunan Daerah. JISIP: Jurnal Ilmu Sosial Dan Ilmu Politik, 1(1).

Pasolong, H. (2007). Teori Administrasi Publik. Alfabeta.

Rezha, Fahmi., et. al. (2013). Analisis Pengaruh Kualitas Pelayanan Publik Terhadap Kepuasan Masyarakat

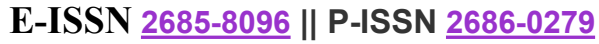

(Studi Tentang Pelayanan Perekaman Kartu Tanda Penduduk Elektronik (E-KTP) Di Kota Depok. Jurnal Administrasi Publik (JAP), 1.

Sindonews.com. (n.d.). Etika Dinasti Politik Atut. https://nasional.sindonews.com/be rita/792393/16/etika-dinastipolitik-atut

Sommaliagustina, Desi. (2019). Implementasi otonomi Daerah dan Korupsi Kepala Daerah. Journal of Governance Innovation, 1(1), 59-76.

Suseno, F. M. (2018). Etika Politik: Prinsip Moral Dasar Kenegaraan Modern. PT Gramedia Pustaka Utama.

Zega, Y. (2018). Analisis Penerapan Etika Birokrasi Dalam Pelayanan Publik Pada Dinas Kependudukan Dan Pencatatan Sipil Kota Gunungsitoli Yamolala Zega Sekolah Tinggi IImu Ekonomi Pembangunan Sekolah Tinggi Ilmu Ekonomi ( STIE) AlWashliyah Sibolga. 1(2), 108-112. 